\title{
Improving Perspective-Taking, Fantasy, Personal Distress and Empathic Accuracy of Students through the Socratic Dialogue Methods
}

\author{
Murdianto \\ Islamic Institute of Sunan Giri (INSURI) Ponorogo \\ murdianto2009@gmail.com
}

Manuscript received: 2 July 2020 | Accepted: 10 October 2020 | Published: 30 October 2020

\begin{abstract}
Four elements of empathy are perspective-taking, fantasy, personal distress, and emphatic accuracy. Empathy is essential for people, especially those who will work as helpers, such as teachers, counselors, nurses, doctors, and other similar professions. This paper studies and measures the effectiveness of the Socratic dialogue method used to increase four elements of student's empathy. This experimental study uses a pretest-posttest control group design. Nineteen participants were selected and divided into the experimental and control group. The experimental results were analyzed by a one-way ANOVA and t-test using SPSS 20.0 for Windows. The results indicate that Socratic dialogue is effective in improving four elements of empathy.

Keywords: empathy, learning model, pre-service education, Socratic dialogue method, teacher candidates.

Abstrak

Empat elemen empati adalah perspective-taking, fantasy, personal distress, dan emphatic accuracy. Empati penting bagi individu, khususnya bagi mereka yang akan bekerja sebagai helper, seperti guru, konselor, perawat, dokter dan profesi sejenis. Penelitian ini menguji efektifitas metode dialog Socratic untuk meningkatkan empati mahasiswa. Penelitian eksperimen ini menggunakan pretestposttest control group design. 19 partisipan terpilih dan dibagi dalam kelompok eksperimen dan kelompok kontrol. Hasil eksperimen ini dianalisis dengan uji ANOVA satu jalan dan uji-t, dengan bantuan program SPSS release 20.0 for windows. Hasil penelitian ini menunjukkan bahwa metode dialog Socratic efektif dalam meningkatkan empati mahasiswa.
\end{abstract}

Kata kunci: calon guru, empati, metode dialog Socratic, model pembelajaran, pendidikan prajabatan. 


\section{Introduction}

The ability to act and take positions in various is one of the social competencies essential to master by an individual (Semrud-Clikeman: 2007, 6-9). These elements are directly related to empathy, an ability to take perspective (perspective taking), and the ability to feel others' feelings. An ability to take perspective (perspective taking) and fantasy is the cognitive domain of empathy. While feeling what others' feelings (empathic concern) and feeling sorry for the others' suffer (personal distress) are the affective aspects of empathy (Batson: 2009).

Empathy is one of the necessary competencies that are important to the individual (SemrudClikeman: 2007). This basic competence is related to the ability to build positive relationships with others. The development of an individual's basic competence is influenced by several key factors: pre-service education, individual personality, self-efficacy, biological/cultural/social, and economic self-perception (Pianta et al, 2003). Mastery of the value of empathy and concern for others is the necessary and vital skill for a helper. In educating people who want to get a profession as a helper, for example, counselors, psychiatrists, teachers, instilling the values of caring for the individual is the primary task in the preparation program for public servants, especially on a teacher (Anderman \& Anderman, 2009).

The development of empathy and concern is one of the central issues that need to develop in the educational process, including in universities, especially students who will fill the role of helping such as teachers, counselors, and psychologists. Dovidio and Penner (2003: 162) noted, "Helping represents an intentional action that has the outcome of benefiting another person". Helping indicates a deliberate act that can give benefits to others. This behavior is based on the value of altruism. Altruistic behavior is mostly determined by the empathy of a person (Pujiyanti, 2009). Empathy is the foundation of morality that makes him capable of giving respect and concern for others. The need for social relations, including the human need for others' empathy, is a basic human need. Empathy from teachers to students will positively impact students' positive attitudes (Salkind, 2008: 342). Thus, it can be concluded that empathy is an essential basis for a prospective teacher, those who design to dedicate his life as a helper.

The findings of previous studies show that empathy can be enhanced with a specific teaching model and methods. Some models and methods are included: role-playing (Douglas \& Coburn, 2005; Clawson, 2006), storytelling, and retelling story (Fritsch et al, 2007). Learning by using short literature, either in the form of poetry, prose, and other literature containing the human dimension (Shapiro, et al: 2004; Shapiro, 2007), reading fiction (Mar, Oatley \& Peterson, 2009). Learning by showing pictures of animals or humans who are victims of a crime is followed by the instruction to use the characters' viewpoint in the image (perspective-taking manipulation) (Schultz, 2000: 391). Learning activities were specifically done to increase empathy among other students, such as learning that presents the direct saying from the parents of children with special needs (Broomhead, 2013). On the students' visit, teachers study visits to the disabled people in which people with disabilities retold their personal experiences related to their disability, then the students noted reflections (Jameson et al, 2006). The increasing empathy through learning can be done with active learning by simulations to others' thinking or feelings through practicing or imitating others' actions in a specific duration (Whitley, 2012). The research of Iqbal et al (2014: 282-289) suggests that empathy can be improved with life skills training. 
The Socratic method was chosen because it has compatibility with a college education, where the students who take teacher education get study. The implementation of Socratic methods has three main steps. They are the case-based approach/social issues, the concept of inquiry, and the method of Socratic dialogue (Hay \& Foley, 1998; Joyce \& Weils, 2003; Singh, 2010; Horsby \& Maki, 2008).

A case-based approach can use short-themed literature with a humanity theme and highlight the position of the victim. The Socratic dialogue is where educators give instruction or questions that can provoke learners' response in a dialogue session. Questions asked are designed to get the imagination and the results of taking the others' perspective that was experienced by learners. The combined uses of short literature on humanity's theme and instructions that can provoke perspective-taking are two treatments that can improve empathy (Schultz, 2000: 391; Shapiro et al: 2004). This learning model is also per the students' age, in which the late teens and early adulthood (Joyce \& Weils, 2003; Singh, 2010).

Besides increasing empathy, the Socratic dialogue method may increase three basic competencies regarding the individual's position in everyday life. First, they are the relativity to the values, second, the ability to clarify and solve problems, third, the ability to master knowledge related to public issues. The Socratic dialogue method in the jurisprudential inquiry learning model can increase individual adults (Singh, 2010). This model is not used in primary education but is used in middle and adult classes (Joyce \& Weils, 2003: 124). In the implementation of the Socratic dialogue method in the learning model, an educator uses various examples of controversial cases containing a moral dilemma that occurs in real life. It is intended to provoke learners' arguments and opinions and a learner's response when faced with classmates' different ethical views. This model encourages the learner to perform criticism of the moral position that has been taken (Hay \& Foley, 1998: 175).

The Socratic dialogue method was adapted for lecture material related to the public issue in adulthood's education level (Joyce \& Weils, 2003: 111.124). The dialogue method was conducted by Socratic to educate his students and performed on the most significant part of the jurisprudential inquiry model (Singh, 2010). Socratic dialogue model can improve students' knowledge and make a learner develop his tendency to have empathy for differences in lecture setting of Pre-position of the teacher (Sauer \& Sauer, 2011: 30; Joyce \& Weils, 2003: 110.124).

The use of empathy-growing learning models, such as the Socratic dialogue model, is essential for teachers candidates. Marjo's (2015: 128) research shows a high level of fundamental empathy for students in counseling study programs in Jakarta 16.91\% upper category, 67.98\% moderate category, and $15.11 \%$ under the category. From this, the findings point to the need for improvement and development of primary empathy student condition. This study confirms the conclusions of Fathurrohman's (2010) study that concluded that a special effort was needed to improve the quality of empathy for student teacher candidates. This conclusion was drawn after mapping the condition of student empathy, starting from the 2003-2006 class.

The facts in lectures at the Faculty of Education at the College have been relying on the lecturer center; the rest is the assignment in writing papers and delivering presentations that were not designed to benefit outside mastery of knowledge and understanding of the lecture material. Lectures which tend to be a monologue and linear lecturer performed, still commonly found in 
lecture meetings. Paper presentations/papers by students are designed in questions and answers form, centered on the materials' content. Even in many cases, they tend to still feel 'stiff' and less dialogue. Thus, the theoretical learning model cannot raise students' empathy because it does not allow for social interaction among students and intense dialogues (Halimah, 2007).

This fact triggered the researcher to improve the quality of the lecture by developing a learning model designed to increase empathy. The research was conducted on a lecture on ethics education. This course discusses the ethics and relation to issues and education policy today. The lecture was held by a learning model that can improve the students' empathy that is the Socratic dialogue method. If previous research has mapped student empathy, this study explores the effectiveness of using the Socratic dialogue model to develop four elements of empathy: fantasy, perspective-taking, personal distress, and empathic accuracy.

\section{Methods}

This study used experimental design research. In this study, the researcher controls or manipulates the study participants of external variables that can influence the experiment and search for specific treatment effects in controlled conditions by randomized sampling. One other feature of this research that shows if it is a kind of experimental design is both samples had no control group or the experimental group (Fraenkel \& Wallen, 2009: 266-267).

The main feature of this design is a) the study participants used two groups; the experimental group and the control group, b) The experimental group was given a specific treatment that was expected to show the effectiveness of The Socratic dialogue method, while the control group was given a different treatment from the experimental group, c) Both groups were given a pretest and posttest before and after the treatment (Fraenkel \& Wallen, 2009: 268). Participants came from students in the Ethics Education course class in the Islamic Religious Education study program IAI Sunan Giri Ponorogo. The instrument used to perform a measure of empathy is the translation of the Interpersonal Reactivity Index (IRI) instrument that has carried out the validation.

This experiment, done from March to May, was conducted through eight sessions: a pretest, six sessions for treatment in the control group and the experimental group, and finally a posttest. To control the possible influence of external variables (extraneous variables) that can affect students' four elements of empathy (fantasy, perspective taking, personal distress, and emphatic accuracy), the researcher has done the following things: 1) Conducting systematic random sampling. Before sampling was done, the researcher made a list of participants based on the gender differences and the first test results for selecting subjects to control the influence of gender differences on the research results. The numbers of male and female participants were pursued to be balanced. 2) The treatment time between the experimental and control groups was separated but carried the same place with a similar setting. Participants of the control and experimental group were controlled during the experiment's implementation by distinguishing the activities' schedules, so they did not see each other. In the hostel, participants were to watch or read any fictional things. 3) Each session was conducted within three days of treatment and implementation. The activities were carried out during midterm holidays when students were not getting another lecture. The treatment was strictly controlled, which the researchers made a practical and applicable guide to all stages, trained by the researcher to the lecturer who carried out the same treatment. 4) Procedures of research were not 
delivered in advance to students as participants, in which each student was asked to go back by the lecturer/instructor in the treatment.

This study uses a pretest-posttest control group design to examine the different effects in the effect of the treatment were tested. In this design, the subjects in the control group remained to receive treatment alternatives. This design is used in a small sample size of fewer than 30 people (Fraenkel and Wallen, 2009: 268). In this case, the control group was treated with the learning commonly used in the Ethics education course, namely case discussion. The designs of this study are in Figure 1.

\begin{tabular}{|llccc|}
\multicolumn{1}{l}{ Groups } & : pretest & treatment & posttest \\
\hline Experiment $(\mathrm{R})$ & $: \mathrm{O}_{1}$ & $\mathrm{X}$ & $\mathrm{O}_{2}$ \\
Control & $(\mathrm{R})$ & $: \mathrm{O}_{1}$ & $\mathrm{C}$ & $\mathrm{O}_{2}$ \\
\hline
\end{tabular}

Descriptions:

$\begin{array}{llll}\mathrm{R} & : \text { Random Sampling } & \mathrm{X} & : \text { Treatment } \text { with the Socratic dialogue method } \\ \mathrm{O}_{1} & \text { : pretest } & \mathrm{C} & \text { : Control with case discussion learning design } \\ \mathrm{O}_{2} & : \text { posttest } & & \end{array}$

Figure 1. Research Design

After randomizing to select participants, students as the research sample were divided into two groups. The first group was treated with the Socratic dialogue method; the second group was treated with the case discussion method (see table 1).

Table 1. The distribution of the subject of the study

\begin{tabular}{|c|c|c|}
\hline Experimental Group & Control Group & Total \\
\hline 10 persons & 9 persons & 19 persons \\
\hline
\end{tabular}

Analysis of variance used in this study was One Way Anova and continued by the t-test. To test the validity of the empathy scale, the researcher used factor analysis to carefully analyze the Microsoft Windows program's statistical software, SPSS release 16.0 for Windows.

\section{Results}

\section{Validity and reliability of the empathy scale}

The validity test conducted by Davis (1980) on the aspects of this instrument resulted in 28 valid items (factor loading $\geq 0.50$ ) from 45 items tested on 221 men and 206 women in psychology introductory classes at the University of Texas USA. The trial resulted in 28 valid items, which were then tested again (confirmatory) on large numbers of subjects, namely 579 men and 582 women, which showed that 28 items were valid (Davis, 1980). The IRI instrument (Davis, 1980) used in this study has actually been tested for reliability by the instrument maker at the University of Texas at Austin, the USA, which produces an internal reliability index of 0.71 to 0.77 , and the consistency of the instrument in various measurements is the same as the test-retest reliability technique. index 0.62 to 0.71 . The distance between the first (test) and second (retest) measurements is 60 to 75 days (Davis, 1980; Jolliffe and Farrington, 2004). 
In the context of this research, the aspects chosen by Davis (1980) are adapted and translated into new instruments for measuring empathy. In the context of this study, the results of the scale development carried out by the researcher were then tested on 280 student respondents aged 19-24 years, consisting of 136 men and 144 women. The respondents were then analyzed using the Pearson correlation technique, obtaining the following results: The product-moment calculation results were then consulted on $\mathrm{r}$ table $(\mathrm{N}=280)$, namely 0.148 . valid items are $\mathrm{r}$ count $>\mathrm{r}$ table, from the above computation results bring invalid items only in item number 25 (twenty-five), that is, with $\mathrm{r}$ count $=0.132$, so item 25 is invalid. Item 25 is then removed, and the remaining 27 (twentyseven) items are then analyzed for a factor. After being consulted on the $r$ table $(N=280)$, which is 0.148 , it shows the invalid items only in item number 25 . After subtracting item 25 , the remaining 27 items are then carried out factor analysis.

The results of the confirmatory factor analysis show, in testing the anti-image correlation repeatedly (three times) the anti-image correlation value $<0.50$ must be removed, indicating that items number 3, number 4, number 12, number 16, number 17, number 20, number 22, number 27 and number 28 were deleted, and could not be continued in further analysis. After the 9 items were removed, only 18 items remained and were analyzed again. The results of the analysis are as follows:

Table $2 \mathrm{KMO}$ and Bartlett's Table

\begin{tabular}{|lll|}
\hline Kaiser-Meyer-Olkin Measure of Sampling Adequacy. & .709 \\
Bartlett's Test of Sphericity & Approx. Chi-Square & 804.339 \\
& Df & 153 \\
& Sig. & .000 \\
\hline
\end{tabular}

From table 2, it can be shown that the KMO MSA value of 0.709 is a good value. Besides, the value of Bartlett's test of Sphericity is 804,339, at 153 degrees of freedom, with a significance of 0 , 000 indicating a good value. Thus, it can be concluded that the empathy instrument is valid in terms of construct validity. Also, the variance of factor loads that can explain empathy shows that the cumulative load of these factors is $43.026 \%$.

The screen plot diagram shows how the decreasing eigenvalue trend is used to determine the number of factors used in Figure 2.

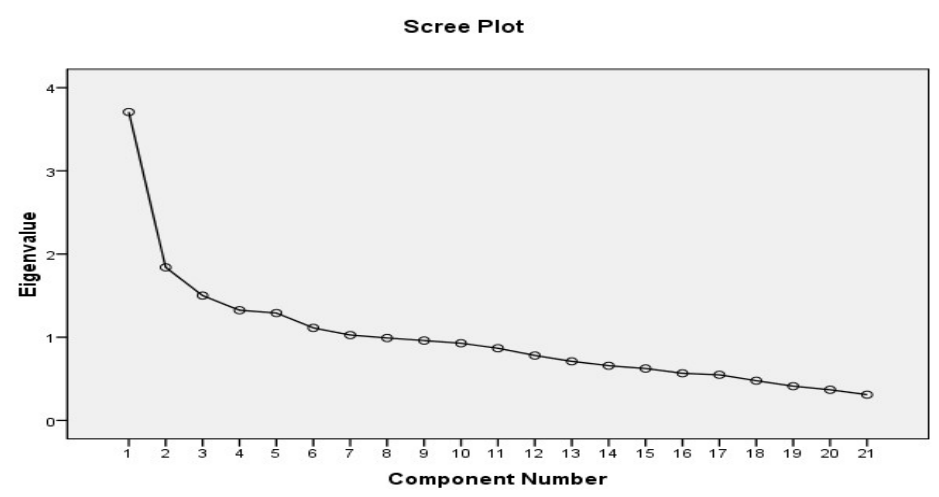

Figure 2 Screen plot of the instrument testing 
The rotated component matrix shows no items $<0.30$, and the highest factor load is in item number 8 , which is 0.766 , and the lowest is item number 6 , which is 0.350 . After passing the item validity test and factor analysis stages, in the end, 9 items $(>0.50)$ remain, and the distribution of items on the 4 (four) factors is as follows:

Table 3 Factor load on retry

\begin{tabular}{|c|c|c|}
\hline Item distribution & Factor & Final item number \\
\hline 2,7 & Fantasy & 1,2 \\
\hline $8,14,15$ & Perspective Taking & $3,4,5$ \\
\hline $24,26,23$ & Personal Distress & $7,8,9$ \\
\hline 18 & Emphatic Accuracy & 6 \\
\hline
\end{tabular}

After the factor analysis was carried out, the items' final results were then analyzed for reliability with SPSS 16.0, indicating that the correlation coefficient obtained was 0.695 , meaning> 0.6 , which is why this instrument was declared reliable (see figure 3 ).

\section{Reliability Statistics}

\begin{tabular}{|cc|}
\hline $\begin{array}{c}\text { Cronbach's } \\
\text { Alpha }\end{array}$ & N of Items \\
.695 & 17 \\
\hline
\end{tabular}

Figure 3 Instrument reliability scores

\section{The assumption test}

This section describes the results of examining the assumptions that are part of using the t-test and ANOVA statistical methods. The assumption examination includes two things: (1) the normality test of data for each group using the Kolmogorov-Smirnov test and (2) the homogeneity test of variance between groups using the Levene's Test. Both checks of these assumptions use the SPSS 20.0 program for Windows. The presentation will be preceded by a description of the results of testing the assumptions and followed by testing the research hypothesis.

\section{Data Normality Test}

One of the assumptions that must be met before the data is further analyzed in the t-test and ANOVA is typically distributed. The normality test results were carried out on the caring score scores on the three indicators in each group. The test was carried out by the Kolmogorov-Smirnov test at the significance level $\alpha=0.05$. The data normality test results for the group's variable score are presented in Tables 4 and 5.

The data distribution test results using the Kolmogorov Smirnov (K-S) aim to determine whether the sample comes from a normally distributed population. The statistical hypothesis in this test is stated as follows:

H0: Data follows a normal distribution

H1: The data does not follow a normal distribution 
If the analysis results prove that the data follows a normal distribution $(\mathrm{p}>0.05)$, the t-test and ANOVA applications can be continued. However, suppose the results of this test do not meet the requirements. In that case, the data transformation will be carried out first, then the data distribution test will be carried out based on the data transformation data results. If data transformation also fails to improve data distribution, the statistical method will be shifted to non-parametric statistical methods.

This section describes the results of examining the assumptions that are part of using the t-test and ANOVA statistical methods. The assumption examination includes two things: (1) the normality test of data for each group using the Kolmogorov-Smirnov test and (2) the homogeneity test of variance between groups using the Levene's Test. Both checks of these assumptions use the SPSS 20.0 program for Windows. The presentation will be preceded by a description of the results of testing the assumptions and followed by testing the research hypothesis.

Table 4 Normality Test Results of Pre-Test Data Distribution

\begin{tabular}{|c|c|c|c|}
\hline \multirow{2}{*}{ Group } & \multicolumn{3}{|c|}{ Kolmogorov-Smirnov } \\
\hline & Statistic & & \\
\hline \multicolumn{4}{|l|}{ Perspective-taking } \\
\hline Control & 0,626 & 9 & 0,828 \\
\hline Treatment & 0,679 & 10 & 0,746 \\
\hline \multicolumn{4}{|l|}{ Personal distress } \\
\hline Control & 0,749 & 9 & 0,629 \\
\hline Treatment & 0,759 & 10 & 0,612 \\
\hline \multicolumn{4}{|l|}{ Fantasy } \\
\hline Control & 1,149 & 9 & 0,143 \\
\hline Treatment & 0,806 & 10 & 0,535 \\
\hline \multicolumn{4}{|l|}{ Emphatic accuracy } \\
\hline Control & 0,976 & 9 & 0,296 \\
\hline Treatment & 1,144 & 10 & 0,146 \\
\hline
\end{tabular}

Note: If the sig value $>0.05$, it means that the data follows a normal distribution

Table 4 shows that the statistical values of the Kolmogorov-Smirnov pretest score of empathy in both the control group and the jurisprudential inquiry treatment followed a normal distribution ( $p>0.05$ ). So that the pretest data has met the assumptions. Furthermore, for examining the distribution of the posttest Empathy data, it is described in Table 5. 
Table 5 Results of Normality Test of Post-Test Data Distribution

\begin{tabular}{|c|c|c|c|}
\hline \multirow{2}{*}{ Group } & \multicolumn{3}{|c|}{ Kolmogorov-Smirnov } \\
\hline & Statistic & Df & $\mathbf{P}$ \\
\hline \multicolumn{4}{|l|}{ Perspective-taking } \\
\hline Control & 0,941 & 9 & 0,339 \\
\hline Treatment & 0,711 & 10 & 0,693 \\
\hline \multicolumn{4}{|l|}{ Personal distress } \\
\hline Control & 1,101 & 9 & 0,177 \\
\hline Treatment & 0,683 & 10 & 0,739 \\
\hline \multicolumn{4}{|l|}{ Fantasy } \\
\hline Control & 0,777 & 9 & 0,582 \\
\hline Treatment & 0,649 & 10 & 0,793 \\
\hline \multicolumn{4}{|l|}{ Emphatic accuracy } \\
\hline Control & 0,670 & 9 & 0,761 \\
\hline Treatment & 0,893 & 10 & 0,403 \\
\hline
\end{tabular}

Note: If the sig value $>0.05$, it means that the data follows a normal distribution

Table 5 shows that the statistical values of the Kolmogorov-Smirnov test of empathy posttest scores in both the control group and the jurisprudential inquiry treatment followed a normal distribution ( $p>0.05)$. So, the posttest data has met the assumptions.

\section{Variant Homogeneity Test}

The test for homogeneity of variance between groups used the Levene test. The variance homogeneity test between groups was carried out to check the similarity of the variance between the two groups. The summary of the results of the homogeneity test of the variance scores is presented in Table 6.

Table 6 Levene's Test Results for Variant Homogeneity

\begin{tabular}{lllll}
\hline Indicator & F & df1 & df2 & p \\
\hline
\end{tabular}

\section{Pre Test}

$\begin{array}{lllll}\text { Perspective taking } & 2,437 & 1 & 17 & 0,164 \\ \text { Personal distress } & 0,143 & 1 & 17 & 0,710 \\ \text { Fantacy } & 5,603 & 1 & 17 & 0,030 \\ \text { Emphatic accuracy } & 0,182 & 1 & 17 & 0,675\end{array}$

\section{Post Test}

Perspective taking 1,255

Personal distress $\quad 0,659$

Fantacy $\quad 0,052$

Emphatic accuracy 0,176

$\begin{array}{lll}1 & 17 & 0,278 \\ 1 & 17 & 0,428 \\ 1 & 17 & 0,822 \\ 1 & 17 & 0,680\end{array}$


In Table 6, it can be shown that the results of the variance homogeneity test in the two groups, both in the pretest and posttest data, are homogeneous $(\mathrm{p}>0.05)$. So, the assumption of variance homogeneity has met.

\section{Pretest Results}

The pretest four elements of empathy perspective-taking, fantasy, personal distress, and empathic accuracy data were divided into control and treatment groups (with the Socratic dialogue method). Table 7 shows the average value and deviation standard fantasy pretest scores in the control group had an average of 5.22 with a deviation standard of 0.83 . In contrast, the treatment group had an average of 6.10 and a deviation standard of 1.60 .

Table 7. Pretest Score

\begin{tabular}{llccc}
\hline Indicator & Groups & $\mathrm{N}$ & Average & Std. Dev \\
\hline Perspective-taking & Control & 9 & 9.11 & 1.05 \\
& Treatment & 10 & 9.00 & 1.76 \\
& Total & 19 & 9.05 & 1.43 \\
\hline Personal distress & Control & 9 & 10.67 & 1.87 \\
& Treatment & 10 & 9.80 & 1.99 \\
& Total & 19 & 10.21 & 1.93 \\
\hline Fantasy & Control & 9 & 5.22 & 0.83 \\
& Treatment & 10 & 6.10 & 1.60 \\
& Total & 19 & 5.68 & 1.34 \\
\hline Emphatic accuracy & Control & 9 & 2.89 & 0.93 \\
& Treatment & 10 & 2.60 & 0.84 \\
& Total & 19 & 2.74 & 0.87 \\
\hline
\end{tabular}

The value of perspective-taking in the control group was 9.11, with a deviation standard of 1.05, whereas the treatment group had an average of 9.00 and standard deviation of 1.76 . The description of empathic accuracy value in the control group had an average of 2.89 , with a standard deviation of 0.93 . The treatment group had an average of 2.60 and a standard deviation of 0.87 . In the personal distress, the control group had an average of 10.67, with a standard deviation of 1.87, whereas the treatment group had an average of 9.80 and a standard deviation of 1.99. Based on the average scores in the two groups, the average pretest scores were relatively balanced, and the standard deviation values were almost the same.

\section{Posttest Result}

This description includes a posttest of perspective-taking, fantasy, personal distress, and empathic accuracy data in the control and treatment groups (Socratic dialogue method). Changes in scores in both groups are described in Table 8. 
Table 8. Posttest Score

\begin{tabular}{llccc}
\hline Indicator & Groups & N & Average & Std. Dev \\
\hline Perspective-taking & Control & 9 & 10.11 & 1.27 \\
& Treatment & 10 & 12.40 & 1.71 \\
& Total & 19 & 11.32 & 1.89 \\
\hline Personal distress & Control & 9 & 10.22 & 1.48 \\
& Treatment & 10 & 12.30 & 1.89 \\
& Total & 19 & 11.32 & 1.97 \\
\hline Fantasy & Control & 9 & 6.00 & 1.12 \\
& Treatment & 10 & 8.30 & 1.25 \\
& Total & 19 & 7.21 & 1.65 \\
\hline Emphatic accuracy & Control & 9 & 2.89 & 0.78 \\
& Treatment & 10 & 3.40 & 0.84 \\
& Total & 19 & 3.16 & 0.83 \\
\hline
\end{tabular}

Table 8 shows that the control group's perspective-taking score had an average of 10.11, with a standard deviation of 1.27. In contrast, the treatment group had an average of 12.40 and a standard deviation of 1.71. The average score and standard deviation of the posttest scores personal distress in the control group were 10.22, with a standard deviation of 1.48. In contrast, the treatment group had an average of 12.30 and a standard deviation of 1.89. On the fantasy, the control group had an average of 6.00 with a standard deviation of 1.12, whereas the treatment group had an average of 8.30 and a standard deviation of 1.25 . The description of empathic accuracy value in the control group had an average of 2.89 with a standard deviation of 0.78 , whereas the treatment group had an average of 3.40 and a standard deviation of 0.84 . Overall empathy posttest scores in the control group had an average of 29.22 with a standard deviation of 2.28, whereas the treatment group had an average of 36.40 and a standard deviation of 4.25 . Based on the average value in both groups, the average posttest score is different, and standard deviation values are almost the same.

Table 9 and 10 show the results of the t-test; the comparison of the average scores of the four elements of empathy pretest versus posttest in the treatment group was significant $(p<0.05)$. The average pretest score of four empathy (perspective taking, personal distress, fantasy, empathic accuracy) increased during the posttest. T-test result and $p$ values have shown significant differences in the scores of the four elements of empathy (perspective taking, personal distress, fantasy, empathic accuracy) during pretest and posttest. 
Table 9. Average t-test results for pretest and posttest on control

\begin{tabular}{|c|c|c|c|c|}
\hline & Average & difference & $\mathbf{T}$ & $\mathbf{P}$ \\
\hline \multicolumn{5}{|l|}{ Perspective-taking } \\
\hline The score during the post-test & 10,11 & 1,00 & 2,268 & 0,053 \\
\hline Score during a pretest & 9,11 & & & \\
\hline \multicolumn{5}{|l|}{ Personal distress } \\
\hline The score during the post-test & 10,22 & 0,45 & 0,595 & 0,569 \\
\hline Score during a pretest & 10,67 & & & \\
\hline \multicolumn{5}{|l|}{ Fantasy } \\
\hline The score during the post-test & 6,00 & 0,78 & 1,941 & 0,088 \\
\hline Score during a pretest & 5,22 & & & \\
\hline \multicolumn{5}{|l|}{ Emphatic accuracy } \\
\hline The score during the post-test & 2,89 & 0,00 & 0,000 & 1,000 \\
\hline Score during a pretest & 2,89 & & & \\
\hline
\end{tabular}

Table 10. Average t-test results for empathy pretest and posttest on treatment

\begin{tabular}{|c|c|c|c|c|}
\hline & Average & difference & $\mathbf{t}$ & $\mathbf{P}$ \\
\hline \multicolumn{5}{|l|}{ Perspective-taking } \\
\hline The score during the post-test & 12,40 & 3,40 & 3,791 & 0,004 \\
\hline Score during a pretest & 9,00 & & & \\
\hline \multicolumn{5}{|l|}{ Personal distress } \\
\hline The score during the post-test & 12,30 & 2,50 & 4,038 & 0,003 \\
\hline Score during a pretest & 9,80 & & & \\
\hline \multicolumn{5}{|l|}{ Fantasy } \\
\hline The score during the post-test & 8,30 & 2,20 & 2,963 & 0,016 \\
\hline Score during a pretest & 6,10 & & & \\
\hline \multicolumn{5}{|l|}{ Emphatic accuracy } \\
\hline The score during the post-test & 3,40 & 0,80 & 2,753 & 0,022 \\
\hline Score during a pretest & 2,60 & & & \\
\hline
\end{tabular}

\section{Major Hypothesis Testing Results}

The hypothesis being tested states that "the use of the Socratic dialogue method effectively improves empathy". The analysis of empathy difference between the control group and the group with the Socratic dialogue method: ANOVA one-way results derived from the Socratic dialogue method is F 20,341 with sig 0,000 . Hypothesis $\mathrm{H} 0$ will be rejected ( $\mathrm{p}<0.05$ ). The test result (table 11) means significant empathy differences in the experimental group by the Socratic dialogue method compared with the control group. So, the Socratic dialogue method model is effective in increasing students' empathy. 
Table 11 ANOVA Result for Empathy

\begin{tabular}{lccccc}
\hline Source & $\begin{array}{c}\text { Sum of } \\
\text { Squares }\end{array}$ & Df & $\begin{array}{c}\text { Mean } \\
\text { Square }\end{array}$ & F & Sig. \\
\hline Socratic & 244,044 & 1 & 244,044 & 20,341 & 0,000 \\
Dialogue & & & & & \\
Error & 203,956 & 17 & 11,997 & & \\
Total & 448,000 & 18 & & & \\
\hline
\end{tabular}

\section{Minor Hypothesis Testing Results}

\section{Minor Hypothesis 1 (H0-1)}

The hypothesis being tested states that "the use of the Socratic dialogue method effectively improves students' perspective-taking". The analysis of the perspective-taking difference between the control group and the group with the Socratic dialogue method is presented in figure 4. ANOVA one-way results derived from the Socratic dialog method is F 10,378 with sig 0,000 , then the hypothesis $H_{0}-1$ will be rejected $(\mathrm{p}<0.05)$. The test result means significant perspective-taking differences in the experimental group by the Socratic dialogue method compared with the control group. So, the Socratic dialogue method is effective in increasing students' perspective-taking.

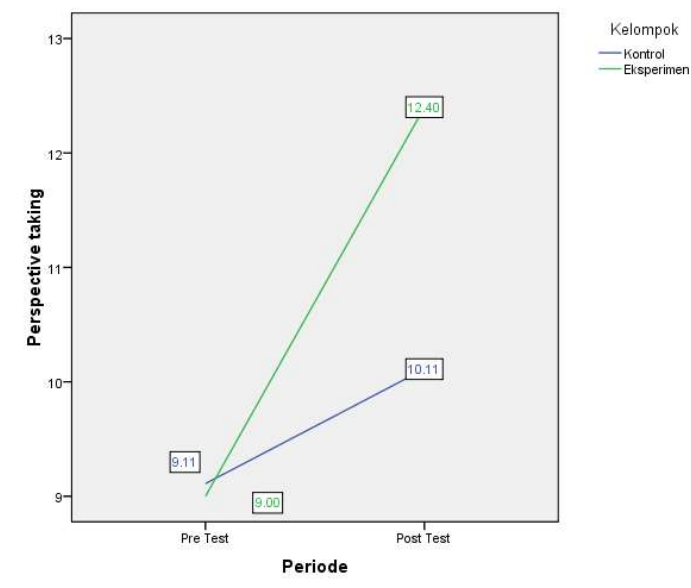

Figure 4. the Socratic dialogue method treatment and perspective-taking

\section{Minor Hypothesis 2 (H0-2)}

The hypothesis being tested states that "the use of the Socratic dialogue method effectively improves students' personal distress". The result of the analysis of personal distress difference between the control group and the group with the Socratic dialogue method is presented in figure 5. ANOVA one-way results derived from the Socratic dialog method is F 7,001 with sig 0,017 , then the hypothesis $\mathrm{H} 0-2$ will be rejected $(\mathrm{p}<0.05)$. The test result means significant personal distress differences in the experimental group by the Socratic dialogue method compared with the control group. So, the Socratic dialogue method model is effective in increasing students' personal distress. 


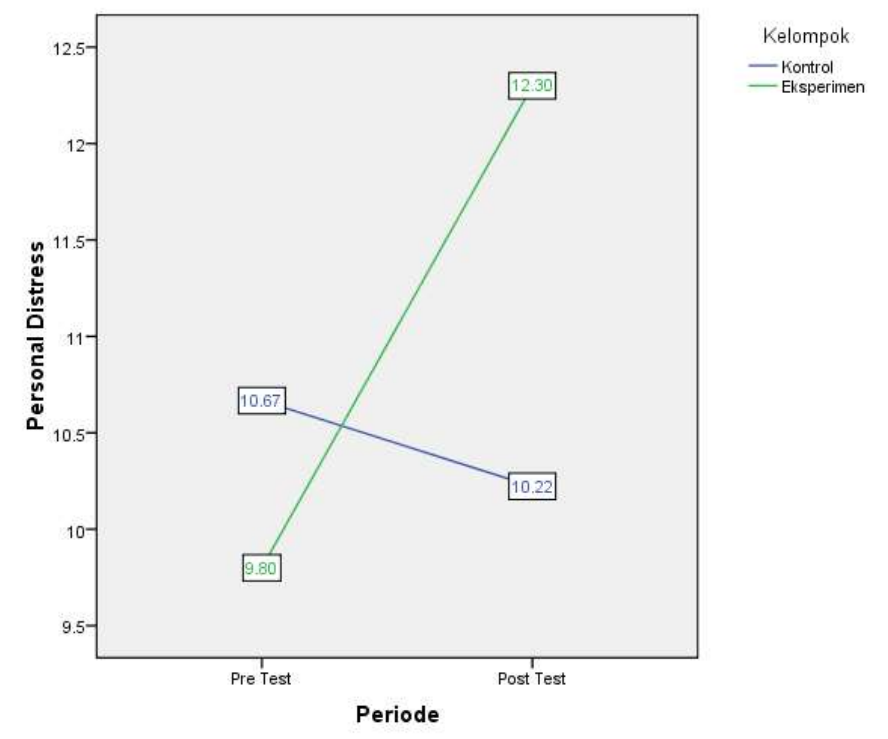

Figure 5 Socratic Dialogue Method Treatment and Personal Distress

\section{Minor Hypothesis 3 (H0-3)}

The hypothesis being tested states that "the use of the Socratic dialogue method effectively improves student's fantasy". The result of the analysis of the fantasy difference between the control group and the group with the Socratic dialogue method is presented in figure 6 . ANOVA one-way results derived from the Socratic dialog method is F 17,676 with sig 0,001 , then the hypothesis $\mathrm{H} 0-2$ will be rejected $(\mathrm{p}<0.05)$. The test result means significant fantasy differences in the experimental group by Socratic dialogue method compared with the control group. So, the Socratic dialogue method model is effective in increasing students' fantasy.

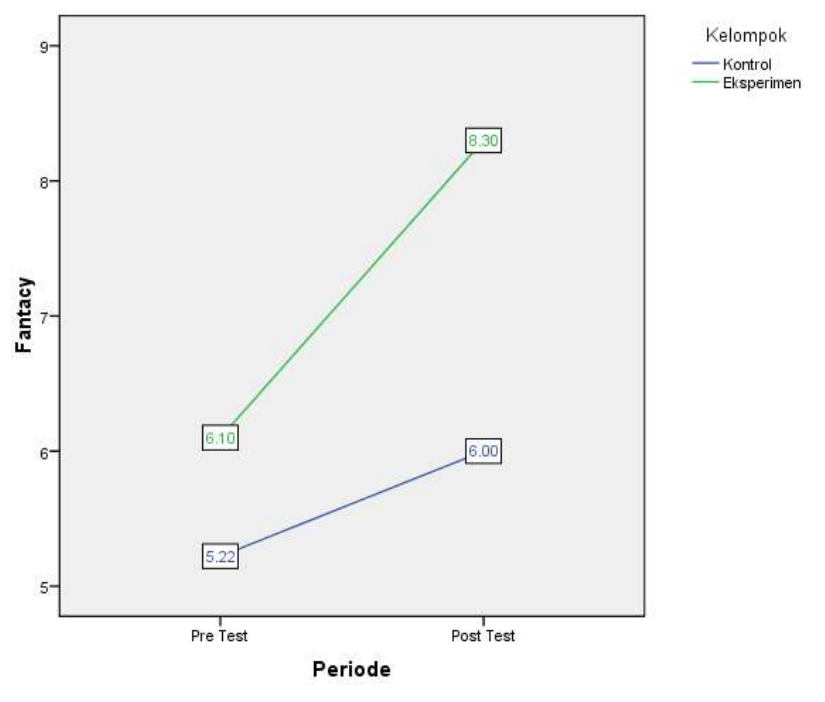

Figure 6 Socratic dialogue method treatment and fantasy

\section{Minor Hypothesis 4 (H0-4)}

The hypothesis being tested states that "the use of the Socratic dialogue method effectively improves students' empathic accuracy". The result of the analysis of empathic accuracy difference between the control group and the group with the Socratic dialogue method is 
presented in figure 7. ANOVA one-way results derived from the Socratic dialogue method is F 1,863 with sig 0,190, then the hypothesis H 0-4 will be received ( $p>0.05$ ). The test result means there are no significant empathic accuracy differences in the experimental group by the Socratic dialogue method than the control group.

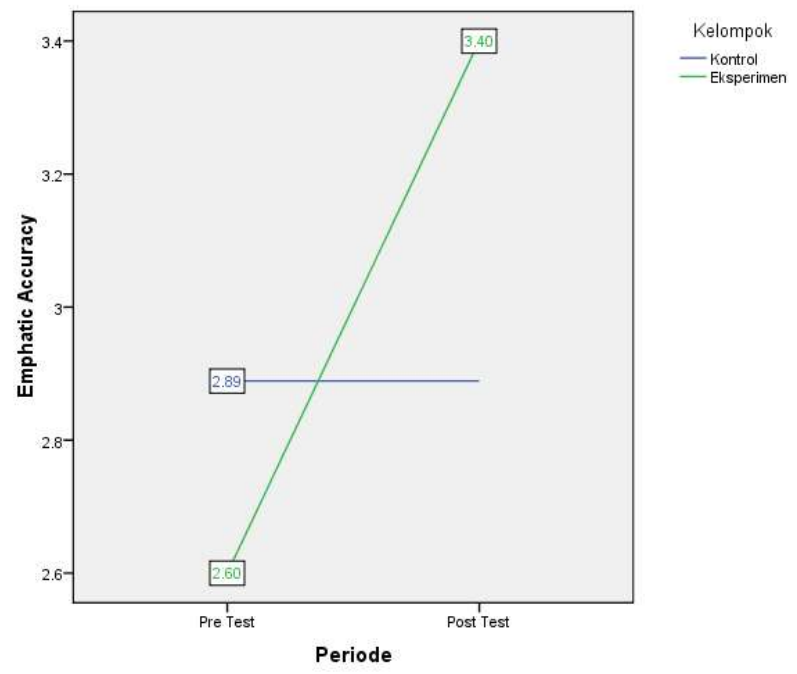

Figure 7. Socratic dialogue method treatment and empathic accuracy

\section{Discussion}

These results indicate an empathy difference between the control group and the group with the Socratic dialogue method. The result of Anova one-way derived from the dialog Socratic method is F 20,341 with sig 0,000 . So the hypothesis $\mathrm{H} 0$ will be rejected $(\mathrm{p}<0.05)$. The test result means significant empathy differences between the experimental group by the dialog Socratic method and the control group. So, the dialog Socratic method is effective in improving students' empathy.

This strengthens Das and Shah (2012: 292-295) research results, which indicates that the development of empathy is influenced by the social environment, including the parenting and learning process. Das and Shah (2012) research shows that teenagers who get good parenting have high empathy. This is reinforced by studies conducted by Knafo et al. (2008) that show the environment's influence in developing one's empathy. The study of Knafo et al. (2008) shows the positive development of empathy. If there are good environmental influences, the development of empathy in adulthood can be maintained.

This study also supports Knafo et al. (2008) 's study that teaching and learning are environmental stimulation that influences adults' development. In this study, adults were the students who take education to be teachers who are still undergoing pre-service education in colleges. This research was set in the lectures process in a college, where the adults get stimulation to respond to various controversial cases in education. The individual response stimulated is the ability to think from others' perspective (in this case, the person as the actor under the setting of the case raised). This effort was conducted to expand their capabilities with more complex and various controversies that they will face in life education. They will have become an educator/teacher in real life. 
The Socratic dialogue method in the jurisprudential inquiry model can reinforce the values of goodness within the individual (Singh, 2010), especially empathy (Sauer \& Sauer: 2010; Joyce \& Weils, 2003). This study's findings indicate that the method can increase empathy, which is the ability of a primary value (core values) that becomes the basis of other good value.

The results also reinforce Singh (2010) research, where the use of The Socratic dialogue method as a learning model was applied in learning settings and small classes to benefit the growth of kindness value. This research was conducted in the class with several participants, 9-10 (nineten). A small class was designed to obtain intensive interaction between educators (lecturers) and learners (students).

Various researches show the Socratic dialogue method, namely 'dealing with issues' by presenting the real-life of learning, can enhance empathy. The presence of real-life was done to retell a story from the real-life (Fritsch et al, 2007), write this fact with brief literature, either in the form of poetry, prose, and other literature containing human dimension (Shapirodkk: 2004; Shapiro 2007), fiction (Mark et al, 2009), show images of animals or humans who are victims of an event (Schultz, 2000: 391). The presence of real-life is presented in a learning process by presenting a testimony from the doers or victims of an event (Broomhead: 2013), then visiting the victim or later asking him to tell his personal experiences related to his disability (Jameson et al: 2006). The presence of reality in the place of learning can also be done with a simulation. Research of Whitley (2012) recommends performing simulations or directly feeling what others feel or think to practice or imitate the others' actions under a certain duration.

A large number of studies, such Fritsch et al (2007), Shapiro et al (2004), Shapiro, (2007), Mark et al (2009), Schultz, (2000: 391), Broomhead (2013), Jameson et al (2006) and Whitley (2012) concluded that bringing the real-life into the learning setting can improve someone's empathy. Presenting real-life directly through a testimonial (Bromhead, 2013), or through literature can provide stimulation for learners to think, feel, and act according to others' viewpoints who become characters the real life.

In line with the previous studies, the researcher presents real-life by composing short writing to describe a case. A chosen case is related to real events in the education process. The case contains moral dilemmas to discuss. This case was taken from the real story of real social life victims, either directly saying or searching for written materials. The case is used to get arguments and opinions of learners. Learners were required to deal with others' ethical views and give critiques of the moral positions that have been taken (Hay \& Foley, 1998: 175). Presenting a case experienced by another person will encourage oneself to change himself imaginatively into the characters' thoughts, feelings, and actions in the case raised. This aspect sees individuals' tendency to put themselves in others' feelings and actions (Davis, 1980; Good et al, 2011).

The increasing of empathy presents real-world activities through quick reading activities related to specific cases over the assembled specific instructions from a teacher or instructor. This instruction was used to find out a view using the perspective view of the character in such cases (perspective-taking manipulation) (Schultz, 2000: 391), or make a reflective note (Boyer, 2012; Broomhead, 2013).

The presence of other people in the described case, along with explorative questions of lecturers, will facilitate the student with a cognitive process to guess others' feelings and intentions. 
The dialogue was also intended to provoke an affective response that appears in the form of anxiety that appears when watching others' suffer. The affective response is part of the elements that are empathy (Hojat, 2007).

The use of short humanity-themed literature was to describe the case and highlight the position of victims. It was then followed by giving Socratic dialogue instructions, which can provoke the imagination and take the others' perspective. Short literature and instructions that can provoke empathy are two methods that can increase empathy, both affective and cognitive standpoint (Schultz, 2000: 391; Shapiro et al: 2004).

The research presents a case study that happens in social issues, encourages learners (students) to take over spontaneously others' viewpoint or look at daily events from the others' perspective (perspective taking), identify themselves in situations experienced by the characters in the case (fantasy). In this study, these instructions were formed in an activity where the teacher asked a question and answered directly through a dialogue. It is called Socratic Dialogue.

Studies conducted by Hamilton and Ullrich (2006: 66) indicate that the Socratic Dialogue application relates the fact into dialogue guided by an educator as a facilitator. Facilitators must be really enthusiastic about giving the issues or cases discussed and reciting dialogue with the learners. The dialogue between educators and learners stimulates learners to imagine or feel the situation as actors. It requires learners to imagine and feel a risk experienced by a character. In this situation, the learners (students) were invited to do a cognitive process that involves self-introspection, objective, and immense effort to get a sense of others' thoughts and feelings. Cognitive empathy refers to how a person suspects others' feelings, intentions, and thoughts properly or not (Maxwell, 2008: 34; Hojat, 2006).

In the Socratic Dialogue, the students deal with various plural arguments, attitudes, and views. Learning design that can meet these differences can enhance the individual learners' empathy and pro-social behavior (Good et al 2011: 27-28). The research of Good et al (2011) also shows that empathy can be built in a dialogical situation between educators and learners in which there are communication skills through listening and questioning and answering activities.

Activities make a written reflection after the dialogue process to strengthen empathy in the final session of dialogue Socratic activities. This strengthens the research of Jameson et al (2006), that an increase in empathy student teachers can be done by linking the real world's experience by making a note of reflection. Research Boyer (2009) suggests that reflective writing is one of the best ways to strengthen empathy and understanding of prospective teachers (Boyer, 2010: 313-321).

From the findings of this study and discussion of previous studies' findings, it can be concluded that the study seeks to combine elements of Socratic dialogue method, wherein each stage of the model is designed to increase empathy at each stage. The case description is written in the format of short literature. This case, followed by a Socratic dialogue that contains a dialogue that encourages individual instruction, imagines an actor in the description of cases, submit answers to spontaneous, and ends with notes reflection that affects the four dimensions that make up the individual empathy. A learning model that can be said to be effective for improving empathy can also increase the entire dimension of empathy, namely: fantasy, perspective-taking, empathic accuracy, and personal distress. These results indicate that an improvement in all dimensions of empathy after the Socratic dialogue method. This research is in line with the conclusions of research 
Iqbal, Rahimi, and Rezai (2014) that the learning model is said to be effective for improving empathy, which means it can also increase the overall dimensions of empathy (Iqbal, Rahimi, and Rezai, 2014: 282-289).

In this study, the increase of personal distress and the three components of empathy (fantasy, perspective-taking, and empathic accuracy) will not negatively affect the individual. Various studies using measurements of the four components of empathy show the same conclusion that the four components rise together in the learning process designed to increase empathy (Vorkapić \& Ruzic, 2013; Iqbal, Rahimi \& Rezai, 2014). However, the increase of personal distress that is more dominant than the other components of empathy can negatively affect the individual. It can decline cognitive awareness. Research by Thomas (2012: 561-585) shows that too high personal distress can entirely interfere with a person's consciousness.

\section{Conclusion}

The analysis of different empathy between the control group and the group with Socratic dialogue methods is presented: the result of Anova one-way derived from the dialog Socratic method is F 20,341 with sig 0,000. So, the hypothesis H 0 will be rejected ( $<<0.05)$. The test result means significant empathy differences between the experimental group by the dialog Socratic method and the control group. So, the dialog Socratic method is effective in improving students' empathy.

\section{Acknowledgment}

I am deeply indebted to my supervisor from the Department of Educational Psychology at Malang State University for inspiration and thoughtful guidance. Finally, I am indebted to my parents, my lovely wife Nuurun Nahdiyyah, my precious son A Ainun Zeva Zachary, and my little daughter Avicenna Hilmy Muthahary, and my institution INSURI Ponorogo for their unlimited support and encouragement for my pursuit.

\section{Bibliography}

Anderman, E.M. \& Anderman, L.H. (Eds.). (2009). Psychology of Classroom Learning. New York: Macmillan Reference.

Batson, C.D. (2009). These Things Called Empathy: Eight Related but Distinct Phenomena. In Decety, J. \& Ickes, W. (Eds.). The Social Neuroscience of Empathy. Massachusetts: The MIT Press.

Boyer, W., (2010). Empathy Development in Teacher Candidates. Early Childhood Education Journal, 10 (38): 313-321.

Broomhead, K. E. (2013). 'You cannot learn this from a book'; pre-service teachers developing empathy towards parents of children with Special Educational Needs (SEN) via parent stories. European Journal of Special Needs Education, 28 (2): 173-186 
Calwson, J.G.\& Haskins, M.G. (2006). Teaching Management. Cambridge: Cambridge University Press.

Das, P.R. \& Shah, A.F. (2012). Impact of parenting on empathy and personal distress among adolescents. Indian Journal of Positive Psychology, 3 (3): 292-295.

Davis, M.H. (1980). A Multidimensional Approach to Individual Differences in Empathy. JSAS Catalog of Selected Documents in Psychology, 10: 85-97.

Douglas, K. \& Coburn, C. (2005). Students Designing Role-Plays: Building Empathy In Law Students? Journal Of The Australasian Law Teachers Association, 61 (120): 55-63.

Dovidio, J.F. \& Penner, L. A. (2003). Helping and Altruism. in Fletcher, G.J.O \& Clark, M.S (Eds), Blackwell. Handbook of Social Psychology: Interpersonal Processes. Massachusetts: Blackwell Publishers.

Fathurrohman, (2010). Kualitas Empati dan Intensi Prososial Sebagai Dasar Kepribadian Konselor. Laporan Penelitian. Yogyakarta: UNY.

Fraenkel, J.R. \& Wallen, N. E. (2009). How To Design and Evaluate Research In Education. New York: The McGraw-Hill Companies Inc.

Fritsch, J., Júdice, A., Soini, K. \& Tretten, P. (2007). Storytelling And Repetitive Narratives for Design Empathy: Case Suomenlinna. Journal of Design Inquiries, Swedia: Stockholm (http://www.nordes.org)

Good, J.S., Fox, J. \& Coffen, R. (2011). Fostering the Development of Empathy in the Classroom: a Strategic Response to The Problem of Bullying. Teach Journal of Christian Education, 5 (1): 24-30.

Halimah, S. (2007). Pengaruh Pembelajaran Berbasis Kompetensi Terhadap Kompetensi Profesional Keguruan: Studi Eksperimen Terhadap Mahasiswa Fakultas Tarbiyah Institut Agama Islam Negeri Sumatera Utara. Disertasi. Bandung: Universitas Pendidikan Indonesia.

Hamilton, P., Ullrich, D. \& Pavelock, D., (2006). The old is new again: using the Socratic teaching method in a graduate student setting. NACTA Journal, 50 (4): 66.

Hay, I \& Foley, P. 1998. Ethics, Geography, and Responsible Citizenship. Journal of Geography in Higher Education, 22 (2):169-183.

Hojat,M.R. (2007). Empathy in Patient Care. New York: Springer Science and Business Media.

Hornsby, K.L. \& Maki, W.M. (2008). The Virtual Philosopher: Designing Socratic Method Learning Objects for Online Philosophy Courses. Journal of Online Learning and Teaching, 4 (3): $391-400$.

Iqbal, N., Rahimi, H. \& Rezai, F. (2014). Effect of Life Skills Training On Empathy of The Iranian High School Students. The International Journal Of Humanities \& Social Studies, 2 (5): 282289.

Jameson, M., Krupa, T., O'Riordan, A., O'Connor, D., Patterson, M., Ball, C. \& Walcox, S. (2006). Developing empathy as a foundation of client-centered practice. The Canadian Journal of Occupational Therapy, 73 (2): 76. 
Joyce, B. \&Weil, M. (2003). Model of Teaching (5th Edition). Boston: Allyn \&Bacon.

Knafo, A., Zahn-Waxler, C., Van Hulle, C., Robinson, J.L.\& Rhee, S.H. (2008). The Developmental Origins of a Disposition Toward Empathy: Genetic and Environmental Contributions. Journal of the American Psychological Association: Emotion, 8 (6): 737-752.

Mar, R.A., Oatley, K \& Peterson, J.B. (2009). Exploring The Link Between Reading Fiction and Empathy: Ruling Out Individual Differences And Examining Outcomes. Toronto: Walter de Gruyter.

Marjo, HK. (2015). Kondisi Empati Dasar Mahasiswa Bimbingan dan Konseling Se-DKI Jakarta. Jurnal Psiko Edukasi, 13 (2), 128-135

Maxwell, B. (2008). Professional Ethics Education: Studies in Compassionate Empathy. Westfälische: Springer.

Pianta, R.C., Hamre, B. \& Stuhlman, M. (2003). Relationships Between Teachers and Children. In W.M. Reynolds, G.E. Miller \&I.B. Weiner (Eds). Handbook of Psychology Vol 7. New Jersey: John Wiley Sons, Inc.

Pujiyanti, A., (2009). Kontribusi Empati Terhadap Perilaku Altruisme Pada Peserta didik Siswi SMA Negeri 1 Setu Bekasi. Jurnal Psikologi Universitas Gunadarma, (Online).

Salkind, N. J., (2008). Encyclopedia of Educational Psychology. Californinia: SAGE Pub. Inc.

Sauer, J. \& Sauer, C., (2010). Challenging Pre-service Teachers' Understanding of the Intersection of Disability and Cultural Diversity. Journal of Praxis in Multicultural Education. 5 (1): 2335.

Schultz, W. P., (2000). Taking on Concern for Environmental Issues Empathizing With Nature: The Effects of Perspective-Taking on Concern for Environmental Issues. Journal of Social Issues, 56 (3): 391-406.

Semrud-Clikeman, M., (2007). Social Competence in Children. New York: Springer.

Shapiro, J., Morrison, E H. \& Boker, J.R., (2004). Teaching Empathy to First Year Medical Students: Evaluation of an Elective Literature and Medicine Course. Journal Education for Health, 17 (1): 73-84.

Shapiro, J., (2007).Using literature and the arts to develop empathy in medical students. Empathy in Mental Illness. Cambridge: Cambridge University Press.

Singh, V. (2010). Effectiveness of the Jurisprudential Inquiry Model of Teaching on Value Inclination of School Students. Journal of Educational Research: Indian Educational Review, 47 (2): $45-71$.

Vorkapić, T. \& Ružić, N. (2013). Measuring Empathy in Future Preschool Teachers: Implications for Study Program Modification. International Journal of Psychology and Behavioral Sciences, 3(6): 188-195.

Whitley, H., (2012). Active-Learning Diabetes Simulation in an Advanced Pharmacy Practice Experience to Develop Patient Empathy. American Journal of Pharmaceutical Education, 76 (10): 203. 